\title{
Model of Integration of Policy Implementation in Poverty Alleviation in Enrekang Regency
}

\author{
Suratman Nur
}

\begin{abstract}
The purpose of the research is to determine the output and outcome decisions on poverty policy implementation in Enrekang Regency, and organizational capacity on poverty policy implementation in Enrekang Regency. In addition to knowing the environmental capacity of poverty policy implementation in Enrekang Regency and to know the characteristics and poverty alleviation programs in Enrekang Regency.

This research took place in Enrekang Regency with three districts namely Maiwa, Enrekang and Anggeraja Districts. The research approach is descriptive qualitative and prioritizing in-depth interviews through interview guidelines in addition to secondary data. Informants / respondents were taken as many as five people who were considered to know the background of this research. Analysis is carried out through descriptive qualitative.

The theory used in studying the problem of poverty in Enrekang Regency Malcom L. Gogging et al. (1990), where the research results showed that output and outcome decisions, organizational capacity, environmental capacity, characteristics and poverty alleviation programs in Enrekang were not optimal. The implementation of poverty policy in Enekang Regency in terms of structural aspects with the formation of several institutions for reducing poverty from central, provincial to regency level policies. As a result, the implementation of poverty policies has not been able to mediate in making significant changes in education, health and employment. In the end, poverty alleviation as in the three cases of research locations namely Maiwa, Enrekang and Anggeraja Districts has not been able to reverse the facts as the BPS indicator standards.

An integrated database of poverty alleviation programs is needed in Enrekang Regency and is more pro-job, pro-poor and pro-growth. Program synergy is needed between stakeholders, so that poverty alleviation programs are more targeted.
\end{abstract}

Keywords: Integrative Model, Policy, Poverty

\section{Introduction}

\subsection{Background}

The problem of poverty is a problem that concerns many circles, especially scientists. This is caused by the many programs aimed at the poor, but have not shown significant results (poverty regeneration occurs). The population in Indonesia is based on preliminary results of the 2010 Population Census reaching 237.56 million people, far exceeding the projection results (BPS, Bappenas, UNFPA, 2005) of 234.1 million. This means that over the past 10 years Indonesia's population has increased by 34.5 million, and $2 / 3$ of them have occurred among the poor population. Thus, the poor population in Indonesia numbered 31.6 million people or 13.3 percent, and the majority of them settled in rural areas with education not completing / completing elementary school. The unemployment rate reached 23.28 million people or 9.8 percent. For this reason, various poverty programs are coordinated directly by technical agencies, starting from the central government to the regional government. It is natural that in 2011, the government has a clear benchmark for reducing poverty to 11.5 to 12.5 percent, and employment of 400 thousand for every one percent of economic growth. Various programs that have become an umbrella have been rolled out, including the poverty alleviation program.

In Enrekang Regency, poverty data per district: Allo District has 5,987 people, Anggeraja District has 4,669 people, Barakka District has 6,622 people, Baroko District 5,810 people, Buntu Batu District has 7,553 people, Bungu District has 2,803 people, Cendana District has 3,278 people, Curio District has 6,730 people, Enrekang District has 10,157 people, Maiwa District has 8,038 people, Malua District has 3,581 people, and Masalle District has 8,661 people (Bappeda, 2016). This phenomenon shows that the poverty problem in Indonesia is still severe, even though various poverty intervention programs (policies) have been rolled out by the Government, but the results have not been effective. Public policy is whatever the government chooses to do or not to do. Implementation as the implementation of policy decisions and programs. There are three models of Public Policy Implementation, namely; top down model, bottom-up model, and synthesis model. 
Top-down and bottom-up models in public policy implementation tend to over-simplify the integrative complexity of implementation. Malcom L. Gogging et al. (1990), explains the variables that influence policy implementation, which include (1) Federal-Level Inducements and Constraints, (2) State and Local Levels of Inducements and Constraints, (3) Organizational Capacity (4) Ecologycal Capacity, and (5) ) Feedback and Policy Redesign. Gogging's views received much appreciation from other scientists and government practitioners.

In fact, these programs tend to be less coordinated and run independently. The linkage as a whole is very weak, so that sometimes it provokes confusion and friction between stakeholders in the region. This condition is even triggered by the many programs with community empowerment jargon and central sectoral programs, which "bypass" (jump over and do not consider) the important role of local government. During the period of regional autonomy, it is very ironic if the problem occurs, because in the autonomous region the aspirations from region and the policies from central meet.

Based on the description above, both phenomena that occur and conceptually, overcoming and empowering the poor involves various stakeholders, so synergy between them is needed, the synergy or cohesiveness between them both policy formulation and policy implementation. In addition, the characteristics of poverty problems are so complex that cohesiveness is a strategy to overcome them.

\subsection{Formulation of the Problem}

Based on this, the research problem formulation is as follows:

1) What are the policies of the central and regional governments on the implementation of poverty policies in Enrekang Regency?

2) What are the output and outcome decisions on poverty policy implementation in Enrekangregency?

3) What is the organizational capacity on the implementation of poverty policy in Enrekang Regency?

4) What is the environmental capacity on the implementation of poverty policy in Enrekang Regency?

5) How is the poverty alleviation program in Enrekang Regency?

\subsection{Purpose of Research}

1) To find out central and local government policies on the implementation of poverty policies in Enrekang Regency.

2) To find out the output and outcome decisions on the implementation of poverty policiesin the regency.

3) To find out the organizational capacity on the implementation of poverty policiesin Enrekang Regency.

4) To find out the environmental capacity on theimplementation of poverty policiesin Enrekang Regency.

5) To find out poverty alleviation programs in Enrekang Regency.

\subsection{Research Urgency}

1) This research is needed to find a new formula in an effort to synergize poverty alleviation.

2) If this research is not carried out, then there is a tendency for poverty alleviation to be carried out sectorally only, so that it will issue inefficient budgets.

This research shows that there is a characteristic description and a model for implementing poverty alleviation programs that has advantages over others. This model description is used as a basis in building an integrated poverty implementation model. This is the initial model in developing an integrative model for poverty alleviation.

\section{Ii. Literature Review}

\subsection{Policy Concepts and Policy Implementation}

One definition of public policy is "Public policy is whatever the government chooses to do or not to do" whatever the government chooses to do or not to do (Thomas R. Dye, 1972). The policy implementation is the implementation of basic policy decisions, usually in the form of laws, but can also take the form of orders or important executive decisions or decisions of the judicial institution of Mazmanian and Sabatier (1983). Successful implementation is relatively difficult if the policies are distributive, the regulative policies are moderate and the redistributive policies are low. Various policy areas have different patterns of relationships, which mean that in the redistributive area there is more bargaining and politicking than in the distributive area, where there may be a great control pressure (Parson, 1997). Malcom L. Gogging et al. (1990), explains the variables that influence policy implementation, which include (1) Federal-Level Inducements and Constraints, (2) State and Local Levels of Inducements and Constraints, (3) Organizational Capacity (4) Ecologycal Capacity, and (5) ) Feedback and Policy Redesign. Gogging's views received much appreciation from other scientists and government practitioners. Gogging Model., at. al, is as follows: 


\section{Gambar 2.1. Implementasi Kebijakan "Communication Model".}

\section{Independent}

Variables
Intervening

Variables
Dependent

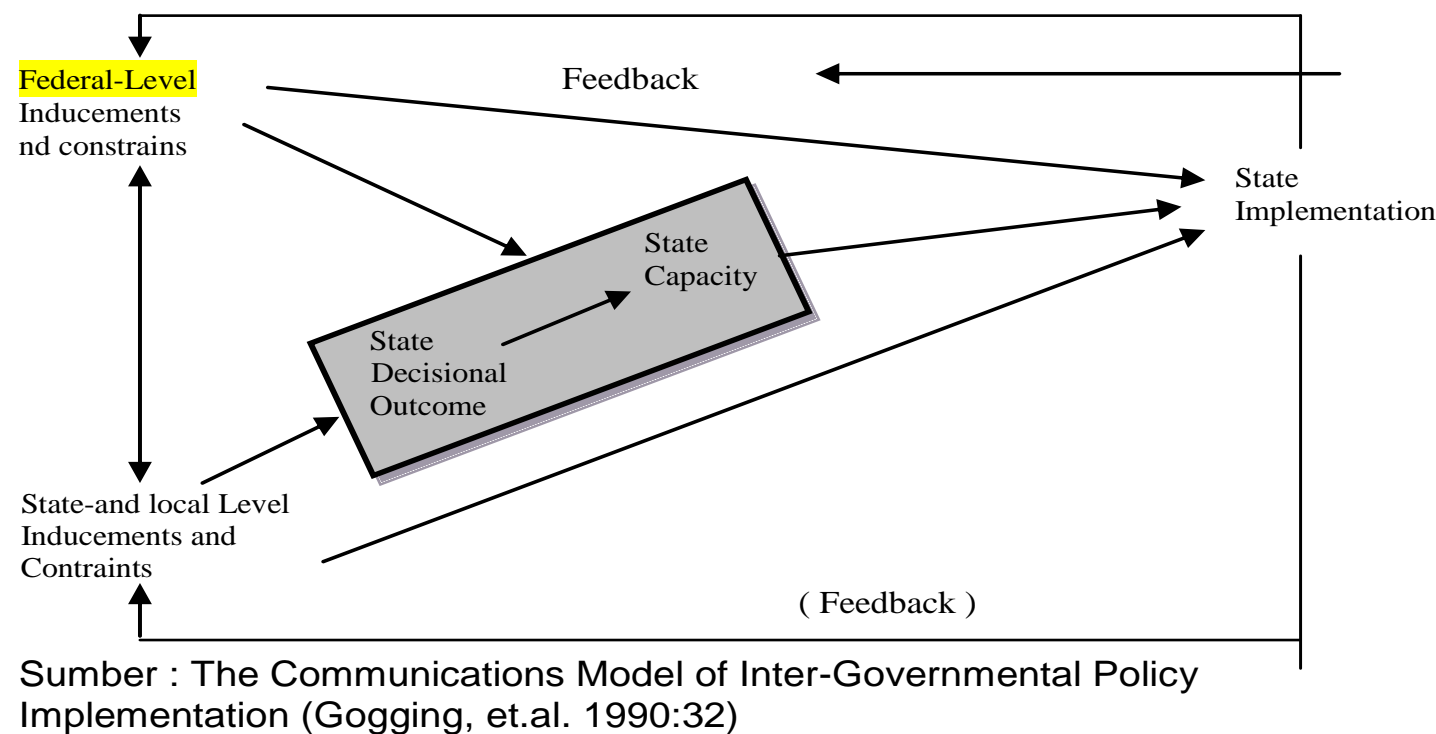

The first component of the Goggin et al. model is the implementation in the area (state). Implementation refers to a process, series of decisions and actions taken by the region that are directed to deliver the mandate of the central decision to a specified effect. The second component of the model of Goggin et al. are stimulants and obstacles at the central level that includes the content of decisions and forms of decisions. The contents of the decision include for example the type of policy, the promised benefits, the level of certainty of the effect, the provisions regarding coercion, the design of funding, the provisions regarding community participation, and so on. Decision forms include, for example, clarity of decisions, consistency of decisions with policy objectives, and flexibility of procedures.The third component of the Goggin et al. are stimulants and obstacles at the regional level. This factor includes three institutional clusters that interact, namely: interest groups, political officials in the region and their political institutions, and implementing organizations. Each institution is assumed to face the problem of sacrifice, in the form of time and money, as well as the problem of obtaining information. The fourth component of the model of Goggin et al. are regional decisions and regional capacities. Decision makers in the regions are recipients and evaluators of the flow of information flowing from the central and regional levels. For implementation to take place, implementation decisions must be made. This often depends on the interpretation of the information they have obtained, while the interpretation itself is closely related to the internal characteristics of decision makers (such as psychological attitudes) and external factors (such as personal relationships with political officials).

\subsection{Definition of Poverty}

Since the publication of the Human Development Report (1997), the United Nations defines poverty as 'the rejection of choices and the most fundamental opportunities for human development - to live a long, healthy, and creative and enjoy a decent standard of life, freedom, pride, and respect for others. "This definition takes into account almost all aspects of human experience - personal, political, social and financial. Since the mid-1990s institutions have realized that poverty affects more than a person's income and consumption habits. The World Bank and others. Meanwhile, according to Chambers (2006: 3), the word poverty contains many different connotations, and what is also quite important is to seek insights and comparisons by inviting local analysts to use their own words and concepts about what is said as poor quality of life and good quality of life.

\subsection{Research Conceptual Framework}

The third model of public policy implementation models (Gogging, et.al. 1990: 32). see clearly that Implementation refers to a process, a series of decisions and actions taken by the region directed to deliver the central decision mandate into a specified effect. The contents of decisions and forms of decisions such as the type of policy, benefits promised, level of certainty of effect, provisions on coercion, design of funding, provisions regarding community participation, and so on. Decision forms include, for example, clarity of decisions, consistency of decisions with policy objectives, and flexibility of procedures. The model of Goggin et al. are regional decisions and regional capacities. 
Decision makers in the regions are recipients and evaluators of the flow of information flowing from the central and regional levels. For implementation to take place, implementation decisions must be made especially regional capacity implementation decisions. The capacity here includes organizational capacity and environmental capacity. Organizational capacity refers to the structural characteristics, personnel and resources of regional government institutions. Whereas environmental capacity refers to the socio-economic and political conditions in the region, so that the variables that determine the implementation of poverty alleviation are; Central Government and regional government policies, poverty objectives, output and outcome decisions, organizational capacity and environmental capacity.

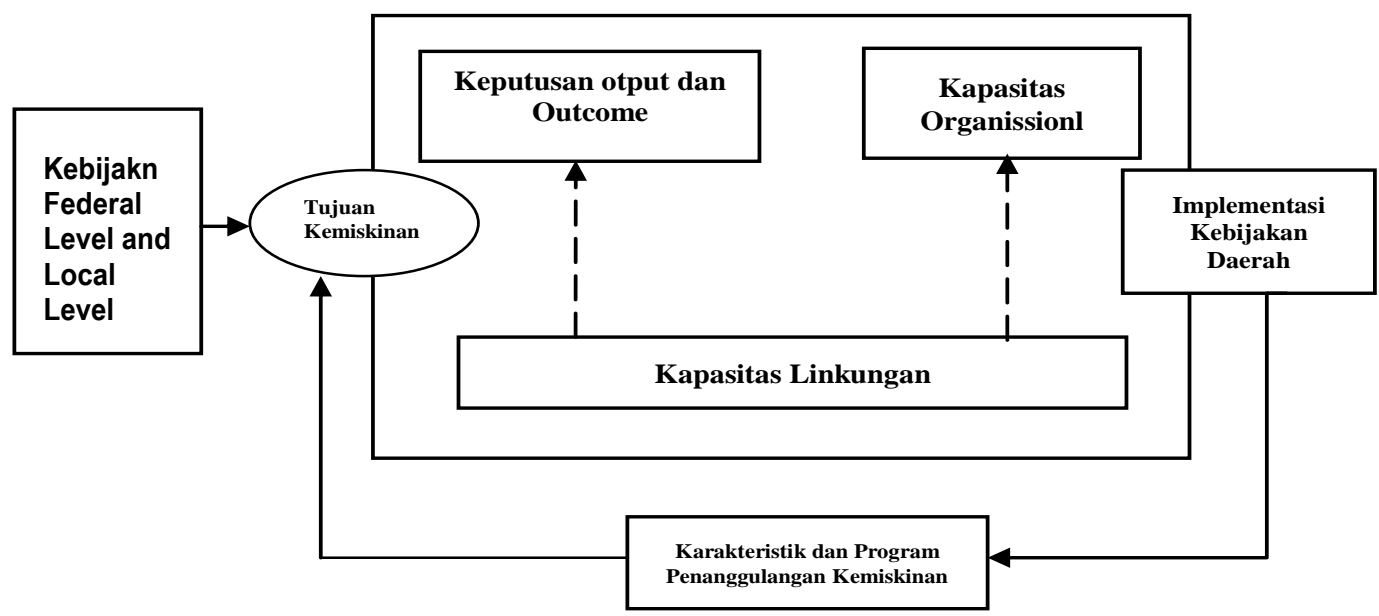

Sumber: Diadaptasi dari Gogging, et.al. 1990:32: The Communications Model of InterGovernmental Policy Implementation

\subsection{The Objectives of Poverty Alleviation Program}

The purpose of poverty alleviation policies according to Bappenas is to reduce poverty levels, including not only efforts to overcome the inability to meet basic needs but also to participate fully in the development process. Achieving the purpose of poverty alleviation is the responsibility of all ministries / institutions, and also considers regional aspects; it means that the way to achieve poverty alleviationpurpose is adjusted to the diversity of regional conditions (www.bappenas.go.id/).

\section{Iii. Research Method}

\subsection{Research Location}

This research is located in Enrekang Regency. This location was chosen because the area is a high enough area of the poor and the implementation of poverty policies has not been fully realized.

\subsection{Research Design}

Research design is a logical arrangement that connects empirical data with research questions, so that a conclusion is in accordance with the facts (Yin, 2000). The design of this research uses qualitative with case study research strategies.

\subsection{Informant}

Determination of informants in the research determined purposively, those who are considered to have competence in relation to the implementation of poverty alleviation programs (Neuman, 1997). The informants in this research are: Chairman of Bapeda and Litbabang in Enrekang Regency, officials / employees of regional technical institutions related to the research problem, the poor in Enrekang Regency, poverty NGOs in Enrekang Regency and community leaders in Enrekang Regency.

\section{4, Research Sample}

Based on the classification of the informant then to determine the sample or subject of the informant is determined in a purposive sample by determining the sample area based on the category of urban and rural areas with consideration of 1 district in the capital city of Enrekang regency, 1 district in the north of the regency of Anggeraja district, 1 southern district of regency of Maiwa district.

\subsection{Research Focus}

The public policy implementation variables are as follows; 
a)Central and regional government policies; a series of decisions and actions taken by the regions directed to deliver the mandate of the central decision to an effect determined in Enrekang Regency.

b) Output and outcome decisions; Output refers to the extent to which programmed objectives can be achieved, while outcomes refer to changes in social problems that the program in Enrekang wants to solve.

c) Organizational capacity; refers to the structural characteristics, personnel and resources of local government institutions in Enrekang Regency. This stage uses a qualitative case study research design with descriptive type.

d)Environmental Capacity; refers to the socio-economic and political conditions in the area in Enrekang Regency.

BPS 2016Poverty Variable

In determining poor households, BPS uses 14 variables to determine whether a household is considered poor. The fourteen variables are: building area; floor type; type of wall; bowel facilities; drinking water sources; source of lighting, type of fuel for cooking; frequency of buying meat, chicken and milk in a week; frequency of eating in a day; and the number of new clothing sets purchased in a year; access to community health center / polyclinics; access to employment; the last education of the leader of the household; and ownership of several assets.

\subsection{Data Collection Techniques and Data Analysis}

To collect data in qualitative research, data collection is conducted through observation techniques, in-depth interviews, and documentation. In accordance with data collection techniques through in-depth interviews, observation and documentation are processed by classification, categorizing, and clarifying data. Data analysis performed was descriptive qualitative analysis (Yin, 2000).

e) Central and regional government policies; a series of decisions and actions taken by the regions directed to deliver the mandate of the central decision to an effect determined in Enrekang Regency.

f) Output and out came decisions; Output refers to the extent to which programmed objectives can be achieved, while outcomes refer to changes in social problems that the program in Enrekang wants to solve.

g) Organizational capacity; refers to the structural characteristics, personnel and resources of local government institutions in Enrekang Regency. This stage uses a qualitative case study research design with descriptive type.

h) Environmental Capacity; refers to the socio-economic and political conditions in the area in Enrekang Regency.

\section{Finding and Discussion}

1) Central and local government policies on the implementation of poverty policies in Enrekang Regency.The first component of the Goggin et al. is the implementation in the area (state). Implementation refers to a process, series of decisions and actions taken by the region that are directed to deliver the mandate of the central decision to a specified effect. Implementation in the region can also be defined from the point of view of outputs and outcomes. Output refers to the extent to which programmed objectives can be achieved, while outcomes refer to changes in social problems that the program wants to solve.

2) Output and outcome decisions on poverty policy implementation in Enrekang Regency. The second component of the Goggin et al. models are stimulants and constraints at the central level that includes the content of decisions and forms of decisions. The contents of the decision include for example the type of policy, the promised benefits, the level of certainty of the effect, the provisions regarding coercion, the design of funding, the provisions regarding community participation, and so on. The types of decision include, for example, clarity of decisions, consistency of decisions with policy objectives, and flexibility of procedures.

3) Organizational Capacity for poverty policy implementation in Enrekang Regency.The third component of the Goggin et al. are stimulants and constraints at the regional level. This factor includes three institutional clusters that interact, namely: interest groups, political officials in the region and their political institutions, and implementing organizations. Each institution is assumed to face the problem of sacrifice, in the form of time and money, as well as the problem of obtaining information.

4) Environmental capacity for poverty policy implementation in Enrekang Regency. The fourth component of the model of Goggin et al. are regional decisions and regional capacities. Decision makers in the regions are recipients and evaluators of the flow of information flowing from the central and regional levels. For implementation to take place, implementation decisions must be made. This often depends on the interpretation of the information they have obtained, while the interpretation itself is closely related to the internal characteristics of decision makers (such as psychological attitudes) and external factors (such as personal relationships with political officials).

5) Characteristics and poverty alleviation programs in Enrekang Regency.

The results of interviews with several informants regarding poverty conditions experienced in the cases of the three research locations indicate that the poverty problem in general has not been able to be optimally resolved or has not been fully integrated, both inter-sectorally and in terms of the approach used. 
An informant from Anggeraja District "Asang" when asked about the frequency of eating meat, chicken and milk said that:

“... We are unable to eat meat, chicken, or milk ... I am here with seven people in this house... and the rice that we cook, the rice is also the distribution of rice for the poor ... only for lunch and dinner ... it is also difficult and expensive to buy fish here ... fortunately we also have a food replacement that is danke to replace fish"(Interview, April 28,2018).

While an informant "Ahmad" from Enrekang District said that:

“... actually eating meat, chicken and milkonly in Eid,both in EidMubarak and Eid Adha ... I can't eat it everyday because it is expensive, so is the fish ...their typical food called danke that is made from cow's milk but not every day only in certain times ... we eat most often twice a day ... but we also usually have breakfast before going to work in the garden or being a motorcycle taxi driver. Usually we onlydrink coffee or teawhenwe rest at home" (Interview, 28 April 2018).

The same thing is almost similar to the statement of "Faridah", the informant from Maiwa District:

“... My house is mostly made of boards, except underneath made of a little wall ... My house is not large but I don't know exactly how large it is ... if you want to defecate there is also a toilet just not using the wall ... For drinking water, I don't have my own well and I took it in the office, there is a well bore there ... There is electricity from PLN, 900 watts ... and when I cook I use wood instead of gas ... If people are sick, they usually go to community health center, my son was riding a motorcycle to bring me there ... I don't have any livestock and the garden is all sold out to others " (Interview, April 29, 2018).

\section{Conclusion and Suggestion}

\subsection{Conclusion}

Based on the research results from various data sources and informants as stated above, it can be concluded that:

a) The implementation of the policy on the poverty alleviation, the Enrekang Regency government shows that it has not been fully felt directly by the target groups or poor families.

b) The output and outcome decisions on the implementation of poverty policies in Enrekang Regency show that they have not been fully felt directly by the target groups or poor families, both the content of the decisions and the form of decisions.

c) Organizational capacity for implementing poverty policies, in terms of structural capacity is actually quite reachable with the formation of several poverty alleviation teams from the local level to the village level and supported by central and provincial policies.

d) The environmental capacity on poverty policy implementation has not shown any significant changes for poor families in terms of the education of the poor, or employment.

e) Then when referring to further poverty alleviation according to some cases of poor families in the three districts, it can almost be said to have in common. By using the BPS assessment standard on the 14 poverty indicators it can be said that factually the poor in Enrekang Regency has not had the full affordability of the existing policies so far. So that the obstacles to accessing welfare improvements are still being experienced.

\subsection{Suggestion}

Based on the conclusions stated above, then the suggestions related to the research results are:

a) An integrated database is needed for poverty alleviation programs in Enrekang Regency.

b) It is necessary to increase the effectiveness of implementing poverty alleviation policies that are pro-job, pro-poor and pro-growth.

c) It is necessary to increase the synergy of poverty alleviation programs and activities carried out by all stakeholders.

d) It is necessary to improve the quality of services and protection that are more directed towards the target groups or based on poor families.

e) Poverty Alleviation Local Regulations are needed to make the poverty alleviation process more effective.

\section{Bibliography}

Alwi\& Suratman, 2010. Analisis Jaringan Antar Organisasi Pelayanan Publik yang Demokratis (Studi Kasus Penyelenggaraan Pelayanan Angkutan Kota di Kota Makassar). Penelitian Hibah Pasca. Lembaga Penelitian Unhas. Makassar. (Tahap 3)

Anderson, J. E. 1979. Public Policy Making. NY: Holt, Rinehart and Winston.

Badan Pusat Statistik (BPS) 2016. Indeks Kesejahteraan Rakyat Kabupaten Enrekang 
Brata, Aloysius Gunadi. 2005. InvestasiSektorPublikLokal, Pembangunan Manusia, dan Kemiskinan. Lembaga Penelitian. UniversitasAtma Jaya. Yogyakarta.

Chemingui, Mohamed Abdelbasset. 2007. Public Spending and Poverty Reduction in an Oil based Economy: The Case of Yemen. Gomanee,

Dye, Thomas R. 1972. Understanding Public fbliy, Englewood Clifls, NJ: Prentice-Hall. Dunn, N. William, 1999. Pengantar Analisis Kebijakan Publik, edisikedua, Yogyakarta, Gadjah Mada University Press.

Dunn, N. William, 1999. PengantarAnalisis Kebijakan Publik, edisikedua, Yogyakarta, Gadjah Mada University Press.

Dziedzic, Nancy; Kepos, Paula (ed). 2007. World Poverty. Information Plusâ Reference Series Formerly Published by Information Plus, Wylie, Texas

Faturochman, et.al.2007, Membangun Gerakan PenanggulanganKemiskinanMelaluiPemberdayaan Masyarakat, Yogyakarta, Pusat StudiKependudukan dan Kebijakan, Universitas Gadjah Mada.

Goggin, Malcolm L. et.al. 1990. Implementation Theory and Practice, Toward a Third Generation. USA: Scott, Foresman and Company.

Howlett dan Ramesh.1995. Studying Public Policy : Policy Cyecles and Policy Subsystems, Oxford University Press.

Isdijoso, Widjajanti, dkk. 2016. PenetapanKriteria dan VariabelPendataanPenduduk Miskin yang KomprehensifdalamRangkaPerlindunganPenduduk Miskin di Kabupaten/Kota. The SMERU Research Institute.

Parsons, Wayne, 2005. Public Policy: An Introdustion to the Theory and Practice of Policy Analysis. Cambridge: Edward Elgar Publishing, Inc.

Mazmanian, Daniel A. Dan Sabiter, Paul A. 1983. Impelementation and Public Policy. Scott, Foresman and Company, New Jersery.

Moleong, Lexy J., 1997. MetodologiPenelitianKualitatif. EdisiRevisi. CetakanKeduaPuluhEmpat. RemajaRosdakarya. Bandung.

Neuman, W. Laurence, 1997.Social Research Methods, Qualitative and Quantitatif Approaches.3rd Edition.Allyn and Bacon. USA.

Pressman, Jeffrey and Aaron Wildawsky, 1973. Implementation. California: University of California Press.

Septiany. 2012. Partisipasi Masyarakat dalamImplementasi Program PNPM MandiriPerkotaandenganmenggunakan model CEAR, p2kp.org/wartaarsipdetil.asp. diakseshariSabtutanggal 3 Mei 2014.

Smith dalam Putra, Fadillah. 2003. ParadimaKritisDalamStudiKebijakanPublik, PustakaPelajar, Yogyakarta.

Yin, Robert K., Prof.Dr. 2000. Studi Kasus : Desain dan Metode. Cet. III, Terjemahan M. Djauzi Mudzakir. Jakarta : Raja GrafindoPersada. 